\title{
1
}

\section{Implementing the Nordic Barnahus Model: Characteristics and Local Adaptions}

\section{Susanna Johansson, Kari Stefansen, Elisiv Bakketeig and Anna Kaldal}

\section{Introduction}

Violence and abuse against children are serious threats to children's well-being, and the need for societies to take action is increasingly recognised, in both the Nordic region and internationally. Children

S. Johansson ( $\bowtie)$

School of Social Work, Lund University, Lund, Sweden

e-mail: susanna.johansson@soch.lu.se

K. Stefansen · E. Bakketeig

Norwegian Social Research, Oslo and Akershus University College of

Applied Sciences, Oslo, Norway

e-mail: kari.stefansen@nova.hioa.no

E. Bakketeig

e-mail: elisiv.bakketeig@nova.hioa.no

A. Kaldal

Law Faculty, Stockholm University, Stockholm, Sweden

e-mail: anna.kaldal@juridicum.su.se

(C) The Author(s) 2017 
exposed to violence and abuse are vulnerable and often in need of multiple services, creating the risk of potential "secondary victimisation". This book targets a model that has been implemented in the Nordic countries for more than a decade, and that attempts to meet children's needs by offering multiple services in child-friendly premises and "under one roof" - the Nordic Barnahus model. The model was first introduced in Iceland and drew on experiences from Children's Advocacy Centres (CAC) in the USA. In this book, the Nordic concept of Barnahus will be used, as it acknowledges the process of translation and adaption that the implementation of the CAC model into the Nordic welfare state context encompasses, and that we will elaborate in this chapter.

In recent decades, violence and sexual abuse against children have been high on the political agenda in the Nordic countries, and a range of preventive as well as legislative efforts has been instigated. The implementation of the Barnahus model is linked to a long-lasting concern for the protection of children at risk and for the way children's needs are met during a criminal investigation, as well as a lack of coordinated follow-up services for children and families that need treatment or support related to the child's experiences.

What are considered legitimate measures for investigating suspected child abuse, including when and how to intervene in family life, differs between societies and over time (cf. Donzelot 1997; Hacking 1999). The introduction of the Barnahus model can be seen as the result of a long process of cultural change in the recognition of violence and sexual abuse against children as a real and widespread phenomena (e.g. Gudbrandsson 2010; Bakketeig 2000). This process of cultural change also encompasses a radical shift in the view of a parent's rights to discipline their children. Throughout the Nordic region, parental corporal punishment has been redefined as an illegitimate act of power and thus as violence. In Sweden and Norway, for instance, laws on parental violence were introduced in the 1970s, and in both countries, new amendments have set a very low bar for what is considered violence (Forsman 2013; Skjørten et al. 2016). Even though legislation may vary between countries, it seems reasonable to see the Nordic countries as characterised by very low and in a legal sense, zero tolerance for violence and 
sexual abuse of children. Both violence and the sexual abuse of children are today seen as a violation of children's basic human rights, in accordance with the UN Convention on the Rights of the Child (CRC) from 1989.

The Barnahus model has been described as one of the main policy ventures related to children as crime victims in the Nordic countries in recent years (Johansson 2012), and the diffusion process in the region has been rapid and extensive. In 2016, all the Nordic countries had implemented the model in some form or other; however, various measures similar to the Barnahus model had been tried out in several Nordic countries in the years before its introduction. In Sweden, for instance, this included a competence centre for child sexual abuse called "Bup-Elefanten" in Linköping, as well as consultation groups for suspected child abuse cases in many Swedish municipalities and recommended by the Swedish National Board of Health and Welfare since the 1990s (see, for example, Swedish National Board of Health and Welfare 2000). These earlier collaborative arrangements were typically not placed in child-friendly localities and under one roof, which are core elements of the Barnahus idea. The implementation of the Barnahus model can thus be seen as a manifestation of an ongoing development of multi-professional child protection interventions aiming at more integrated and child-centred models for handling suspected child abuse.

The establishment of the Barnahus model should also be seen as related to the partly overlapping development of broad policy packages to prevent all forms of domestic violence in their respective countries and thus not solely related to violence and abuse against children specifically. In Norway, for instance, the work in this field has been coordinated through a series of governmental action plans, and the current government is launching a wide-ranging plan to strengthen policies of domestic violence in 2016.

Barnahus is often referred to as an example of child-friendly justice, and the model is currently promoted at the European level by the Council of Europe (see, for example, Council of Europe 2010). Several European countries are now in the process of implementing multi-professional measures regarding investigations of child abuse, inspired by the Nordic Barnahus model. For example, a Barnahus was opened in 
Lithuania in June 2016, following an initiative from the government. ${ }^{1}$ In November 2015, the government in Cyprus decided to open a Barnahus, and a working group has been established for the implementation process. Initiatives have also been taken in the UK. Recently, we also learned that Barnahus may be tried out by UNICEF in Kazakhstan.

This situation warrants discussion. What are the characteristics of the Barnahus model? And what are the challenges and prospects of the Barnahus model within a Nordic welfare state context? Experiences and comparative knowledge from the different Nordic Barnahus contexts could, in turn, be of value when discussing the implementation of the Barnahus model (or similar integrated and multi-professional services) outside the Nordic welfare state context, as well as to further the development of collaborative and investigative Barnahus work within the Nordic countries. ${ }^{2}$

One perspective that will be put forward in this chapter and throughout the book is that the diffusion and implementation of the Barnahus model may be seen to be a continuous transformation of ideas rather than simple copying or imitation (Czarniawska and Sevón 1996; Røvik 2000, 2016; Johansson 2012). In this introductory chapter, we will use a contextual and comparative perspective to highlight how the model is shaped by the legal and organisational context into which it has been introduced. We start, however, by discussing the core elements encompassed by the Barnahus model_as an idea and as a distinct model of collaborative work in cases of violence and sexual abuse against children.

\section{The Barnahus Idea}

A first question for readers of this book, and for states, agencies or professionals discussing whether to implement the Barnahus (or a similar) model, would be what the Barnahus model is, and what core elements must usually be in place or regarded as necessary for an intervention to fall within the Barnahus category. In other words, what does the Barnahus idea consist of? And how does the Barnahus model relate to, and differ from, other measures and interventions for child victims 
of abuse participating in legal processes, such as the US Children's Advocacy Centres (CAC)? ${ }^{3}$

The concept "Barnahus" translates as "Children's House" in English and originates from Iceland, the first Nordic country to adopt the model in 1998. The Icelandic Barnahus took the CAC model as its inspiration, which developed as a response to child sexual abuse, starting in Huntsville, Alabama, 1985. The CACs currently number nearly 1000 centres across the USA (http://nationalcac.org). Both models build on the understanding that child abuse is a complex phenomenon, demanding highly specialised expertise and coordinated services.

\section{A Multi-professional Approach}

Both Barnahus and CACs represent multi-professional approaches to child victims of abuse with the double aim of facilitating the legal process and ensuring that the child receives necessary support and treatment. The multidisciplinary team concept is, for example, a core element of the CAC model. At both European and international levels, guidelines and policy documents on child-friendly justice stress the importance of close multidisciplinary collaboration in child-friendly facilities (Lanzarote Convention; Council of Europe 2010; FRA 2015; UN Economic and Social Council resolution 2005/20; CRC/C/ $\mathrm{GC} / 12$ ). Some specifically mention Barnahus as an example of a promising practice to this end (see Council of Europe 2010).

The agencies involved most often encompass law enforcement, child welfare services and health care, and thus professionals such as social workers, psychologists, police and prosecutors, paediatricians and forensic doctors. The practice of consultation meetings around suspected child abuse cases is central when it comes to the organisation of multiprofessional collaboration within the Barnahus model; however, it is important to note that there are variations regarding the agencies and professions involved-not only between the CACs and the Barnahus model, but also between different Nordic Barnahus models, as will be further discussed later in this chapter. 


\section{The One Door Principle}

Both the CAC model and the Barnahus model are guided by the "one door principle" (or the "under one roof principle") meaning that professionals should come to the child and not the other way around. Barnahus has, for instance, been described as containing four rooms: the criminal investigation, protection, physical health and mental health, with a roof at the top representing knowledge (Landberg and Svedin 2013). Save the Children, as an important agent in promoting Barnahus in the Nordic countries, has argued that the establishment of Barnahus and the one door principle is necessary from a child rights perspective (e.g. Skybak 2004; Save the Children Sweden 2009; Landberg and Svedin 2013). Barnahus would save children from the stress of being shuffled between public services, having to repeat their story over and over again, and often in environments that children experience as strange and sometimes even frightening. Such services were often poorly coordinated, suggesting that the investigations were not taking place at the premises of the child (Skybak 2004).

\section{Avoiding Secondary Victimisation}

Closely related to the one door principle is the idea of avoiding repeated contacts and interviews by multiple professionals in localities not adjusted to children's needs and thus to reduce the risk of "secondary victimisation". Both the CAC and the Barnahus models are thus supposed to be child friendly, or child centred, and sensitive, meaning that the measure shall not cause extra harm. Preventing the child being (re) victimised by the criminal process is often highlighted as important (see, for example, Skybak 2004). This core element is primarily materialised through the joint child investigative interview (see Gudbrandsson 2010) and thus the co-hearing of the interview in an adjacent monitor room at the Barnahus, where the idea builds on a multi-professional observation in order to avoid repeated interviewing, as well as making use of the specialised competences. Cross et al. (2007), for instance, describe how the joint interview is supposed to limit the number of interviews as well as interviewers (Cross et al. 2007). 


\section{A Safe Place for Disclosure and Neutral Place for Professional Interventions}

Another core element of the Barnahus idea is that it is supposed to be a safe place for disclosing abuse (see Gudbrandsson 2010; Stefansen, Chap. 2), often interpreted as a child-friendly, child-centred and supportive setting, as well as a place that is safe from persons suspected of abuse. This is intended to provide the best possible circumstances for children to disclose abuse, and to feel safe, thereby avoiding secondary victimisation. Partly related to this core element, and partly to the one door principle, is also the localisation of Barnahus. There have been, for instance, ongoing discussions concerning the importance of Barnahus being localised in a residential area as opposed to a more office-like or agency-typical location. Similarly, there have been discussions concerning the importance of the medical examinations being held at the Barnahus as opposed to a nearby hospital (cf. Stefansen et al., Chap. 16).

In contrast to the CAC model, however, a specific characteristic of the Nordic Barnahus model is the fact that the child does not testify in court and therefore does not appear in court, as will be described further below. The Nordic Barnahus model thus represents a place away from the premises of the criminal justice system, while at the same time ensuring the child's right to participation and access to justice, without compromising the right to a fair trial for the suspected offender. The idea of Barnahus is thus, in addition, to represent a neutral space for professional interventions. The coordination of parallel and different professional investigations and interventions is, for example, to be balanced sufficiently, as are the partly conflicting interests of child-friendly justice and the principle of a fair trial. This element of the Barnahus idea is also concretely materialised in the Barnahus locality, through, for instance, the design of the interview room in a neutral but calming style, while other rooms are more stimulating.

\section{A Broad Target Group and Definition of Child Abuse}

The CACs, as well as Barnahus in Iceland, were launched as a measure for handling sexual abuse cases. Today, the Barnahus model within the Nordic countries most often encompasses both sexual abuse and 
violence cases. As illustrated in the appendix of this book, all Nordic countries, except Greenland, now include children being victims of both sexual abuse and physical (interpersonal) violence, in the target group of Barnahus. In fact, the majority of cases handled in Swedish and Norwegian Barnahus, for instance, involve suspicions of physical abuse where either one or both of the child's parents are suspected offenders (see, for example, Åström and Rejmer 2008; Kaldal et al. 2010; Bakketeig et al. 2012; Stefansen et al. 2012). ${ }^{4}$

In this chapter, and throughout the book, we will thus use "child abuse" as a generic term since it encompasses both violence and sexual assault, thereby including the target groups of all Nordic Barnahus models, and differentiate more specifically when relevant.

\section{The Nordic Welfare State Context}

We consider a description of the Nordic welfare state context important in order to understand the implementation process of the Barnahus model within the Nordic region. The Barnahus model can be understood as a service at the intersection of the child welfare system and the criminal justice system, making a description of these systems especially relevant. Since the implementation of the Barnahus model takes shape in relation to-and operates within - the distinct child welfare and criminal justice systems of the Nordic countries, the following section introduces the central characteristics of these systems within the Nordic welfare state context. This section also functions as a contextualising background for the next chapters of the book, as well as this chapter's comparative analysis of the implementation processes within the Nordic countries more specifically.

The Nordic countries are often described as well developed and similar when it comes to welfare and justice systems, for example, as belonging to a "Nordic welfare model", a "social democratic welfare regime" or "the Scandinavian model" (e.g. Esping-Andersen 1990; Lorenz 1994; Gilbert et al. 2011; Forsberg and Kröger 2011). Christiansen and Markkola (2006: 11) point out that “(..) some general assumptions are made about the Nordic welfare states. They are supposed to 
be characterised by a strong state, or more correctly, a large and expensive public sector; welfare benefits and services (...)". Even though the Nordic welfare model secures general benefits for citizens, it has primarily focused on the rights of adults or families, and not young people and children as independent actors in their own right (Backe-Hansen et al. 2013); however, this has been challenged by both a new understanding of childhood that sees children as competent agents and an increased focus and emphasis on children's rights through the development and ratification of the CRC (cf. James and Prout 2014 [1990]; Freeman 2012). The CRC has been ratified by all the Nordic countries and, for instance, been incorporated in full by Norway and suggested to be incorporated in Sweden. ${ }^{5}$ The core message of the CRC is that the child is an individual holder of fundamental human rights that not only derive from their vulnerability but from a recognition of the child as a subject. $^{6}$

\section{The Child Welfare System}

Child welfare systems in the Nordic countries are often described as "family service-oriented" in contrast to "child protection-oriented" systems in English-speaking countries such as the USA, Canada and the UK (Gilbert 1997; Gilbert et al. 2011). Since family service-oriented systems are primarily based on ideas about child welfare, they typically focus on early prevention and thus cover a broader target group. Services are mostly directed towards support for the family as a whole and based on voluntary measures and collaboration as a first option, and compulsory interventions as an exception. Child protection-oriented systems, on the other hand, have a more restricted focus, targeting abused or neglected children more specifically and not usually families in need of more broad support. Measures undertaken by child welfare services in child protection-oriented systems are usually introduced later and are typically more protective, controlling and legalistically based (e.g. in the sense of using investigatory and coercive means) (Gilbert et al. 2011). These differences also affect the number of cases that enter the child welfare system. In Norway, for example, a more family service-oriented 
system has resulted in a strong growth in the number of children who receive some kind of services from the child welfare system, thus increasing the potential to identify children in need of support at an earlier stage and to work more preventively. The increase in cases reaching the child welfare system has, in turn, been discussed in relation to the potential risk of developing a child welfare system with fewer resources left for children at greater risk, by contributing more to the general level of welfare than addressing children and families with more serious dysfunctions (Backe-Hansen et al. 2013; cf. Ponnert 2015).

In addition to the similarity in terms of a traditional family service orientation among the Nordic countries, there are also organisational differences between the respective child welfare systems (cf. Blomberg et al. 2011). This includes, for instance, whether child welfare is being regulated and organised as an independent body (as, for example, in Norway), or as part of a municipality's general social services system (as, for example, in Sweden). Being a specialised service may imply more targeted services (Backe-Hansen et al. 2013), but may also imply a risk of fragmentation in relation to dealing with social issues within the family. It may also affect the implementation of the Barnahus model in different ways, as several of the contributions in this book will illustrate.

The regulatory framework of mandatory reporting to the child welfare services among the Nordic countries means that there also are developed systems for child protection within the Nordic countries. ${ }^{7}$ Several recent legislative changes have also been aimed at strengthening the protection of children at risk. This means that the child welfare systems within the Nordic welfare states tend to contain both elements of family service orientation and child protection orientation. Family service-oriented systems have been criticised for emphasising custodian rights at the expense of children's rights and needs (e.g. Kaldal 2010; Leviner 2011); however, it has been stressed that different child welfare systems, including the Nordic country systems, are moving towards the mix and convergence characterised by more "child-focused-oriented" systems (Gilbert et al. 2011). This convergence can be partly understood in the light of the strong standing of children's rights, because child participation has gained increased attention both in research and as an important element of child welfare work (Gilbert et al. 2011). 


\section{The Criminal Justice System}

\section{Child-Friendly Justice}

The idea of child-friendly justice has developed and materialised in a number of international treaties and policy documents (see above) since the signing of the CRC. The idea is associated with two discourses: on the one hand, a discourse of protection that sees children as vulnerable, and on the other hand, a discourse that sees children as agents with the ability to act on their own behalf (Sandberg 2016). Both discourses are reflected in the Nordic legal systems.

A common characteristic of the criminal justice systems in the Nordic countries is that children do not give evidence in court. The best evidence rule and the adversarial principle are basic in legal procedure. These principles are sanctioned in the Convention for the Protection of Human Rights and Fundamental Freedoms article 6, the right to a fair trial. The core of the right to a fair trial is the defence's right to crossexamine a witness, art. $6.3 \mathrm{~d}$. According to this, evidence shall be given in court so that the accused can defend themselves against the charges. In the Nordic countries, when the aggrieved party is a child, their testimony is given outside of the court proceedings. The European Court of Human Rights has ruled in several cases that a testimony given in the pre-trial (criminal) investigation does not violate the defendant's right to a fair trial if the defendant's rights according to article 6 have been safeguarded in the pre-trial investigation (Danelius 2015; Hennum 2006; Sutorius and Kaldal 2003).

Historically, the child's need for protection has been a central justification for the child's testimony to be given outside of open court. In Norway, for instance, this practice was first implemented in sexual abuse cases. It has later expanded to cases involving physical violence and children witnessing violence. In Sweden, the Supreme Court ruled in 1963 (NJA 1963, 555) that a child's audio-documented statement from the police investigation could be used as evidence despite the breach of the fundamental principle of evidence immediacy. The Barnahus model can, against this background, be seen as part of a 
development aimed at protecting children against the burden that the investigation and court proceedings can represent for the child. In Barnahus, children give their testimony in child-friendly environments, and their testimony is video-recorded. Child-friendly environments can be seen as a way of orchestrating the best possible setting for the child to give their testimony, in accordance with the child's right to participation as stated in the CRC. The committee states that the hearing must be child friendly with regard to environment and procedures $(\mathrm{CRC} / \mathrm{C} /$ $\mathrm{GC} / 12$ ). This brings us to the child rights perspective.

\section{The Child Rights Perspective}

The child rights perspective has influenced criminal law as well as other legal areas, such as child and family law and child welfare law. According to international law, children are granted legal protection from violence and abuse. This is stated in both the European Convention on Human Rights (art. 3), as interpreted by the European Court of Human Rights, and CRC, in, for instance, articles 19 and 34. Article 39 obliges states to implement measures to protect children from violence and abuse.

The child's right to participation is a basic right that follows from CRC article 12. Participation is one of the four main principles in the convention. It is an independent right, as well as a right integral to all the other rights that the CRC entails (Sandberg 2016). The right to participation applies to all issues concerning the child and includes the child right to access justice. The UN Committee on the Rights of the Child does not make any distinction as to whether the child is a witness to or a victim of crime. The child therefore has an independent right to be heard in cases of violence and abuse in a criminal case and in all stages of the legal process. The best interest of the child is another basic right and fundamental legal principle in the CRC (art. 3). This means that if a provision is open to more than one interpretation, the interpretation which most effectively serves the child's best interest should be chosen $(\mathrm{CRC} / \mathrm{C} / \mathrm{GC} / 14)$. The principle of the best interest of the child is also a procedural principle. This means that when a decision relates to 
a specific child, the decision-making process must entail an assessment of the consequences of the decision for the child (CRC/C/GC/14).

The consideration of the child's need for protection (child-friendly justice) and participation (the child rights perspective) may conflict. Numerous studies have shown that the relationship between these two considerations is complicated. For instance, even though the child has a right to participate in all matters affecting them, several studies show that the child is not always heard (Bakketeig and Bergan 2013; Eriksson 2012; Kaldal et al. 2010). Protecting a child is often used as an argument for not hearing the child, even though this is not in accordance with the rights of the child. On the other hand, the right to participation does not imply a duty to participate; there must therefore also be consideration of the right of the individual child to not participate.

\section{The Nordic Barnahus Model(s)}

The fact that the Barnahus model has spread and is established in all Nordic countries could in one sense be interpreted as a sign of the similarities between the Nordic welfare states sketched above, but in the light of several completed as well as ongoing studies of Barnahus in the different Nordic countries (e.g. Åström and Rejmer 2008; Swedish National Police Agency et al. 2008; Kaldal et al. 2010; Johansson 2011; Bakketeig et al. 2012; Stefansen et al. 2012; Johansson 2012; Landberg and Svedin 2013), important variations regarding the implementation of the Barnahus model are crystallising. This actualises the importance of gathering knowledge from the different countries, as well as further developing an interdisciplinary, contextual and comparative understanding. In this section, we will compare how the Barnahus model has been implemented in the different Nordic countries on an overarching level, and address differences and similarities in aims and scope, as well as legal and organisational aspects of the different national models. We will thus identify key characteristics of the local adaptions of the Nordic Barnahus model that, in turn, will work as an introduction to the following chapters of the book. 


\section{Comparing Key Characteristics and Local Adaptions}

The Nordic region consists of the five countries: Iceland, Sweden, Norway, Denmark and Finland, as well as their autonomous regions: the Alland Islands, Greenland and the Faroe Islands. In the following, we will address the key characteristics, as well as local adaptions, of the Nordic Barnahus models. Table 1.1 gives an overview of the key characteristics of the national Barnahus models in Iceland, Sweden, Norway and Denmark, based on the more detailed country model descriptions in the appendix of this book (which also include descriptions of the models in Finland and the autonomous Nordic regions). The main arguments for only including Iceland, Sweden, Norway and Denmark in the table are that they are the Nordic countries where Barnahus is most widespread and/or where most evaluations and research have been undertaken so far, so that the data available are robust and thus comparable. To some extent, however, all Nordic countries and regions will be part of the comparative discussion.

There are, of course, challenges when including comparable elements in a table like this one (Table 1.1). First, there are often discrepancies in data regarding how the Barnahus model on an ideological level is defined in the respective countries and how it functions in practice. For example, the target group could be defined more broadly in policy documents or regulations, while in practice reaching a more limited group of children, or vice versa. Secondly, there are difficulties in finding comparable data, resulting in various sources being used to describe the models in the different countries, even though we have tried to use additional sources in order to make the information as comparable as possible, as well as primarily focused on the four country models with most available data sources. Third, there are difficulties connected to the constant change that the collaborative Barnahus model is undergoing in respective countries, as well as local variations in implementation within countries (which applies more to some countries than others). Despite these difficulties, we have identified significant similarities and differences between the Nordic Barnahus models on an overarching level, which will be discussed in the following. 


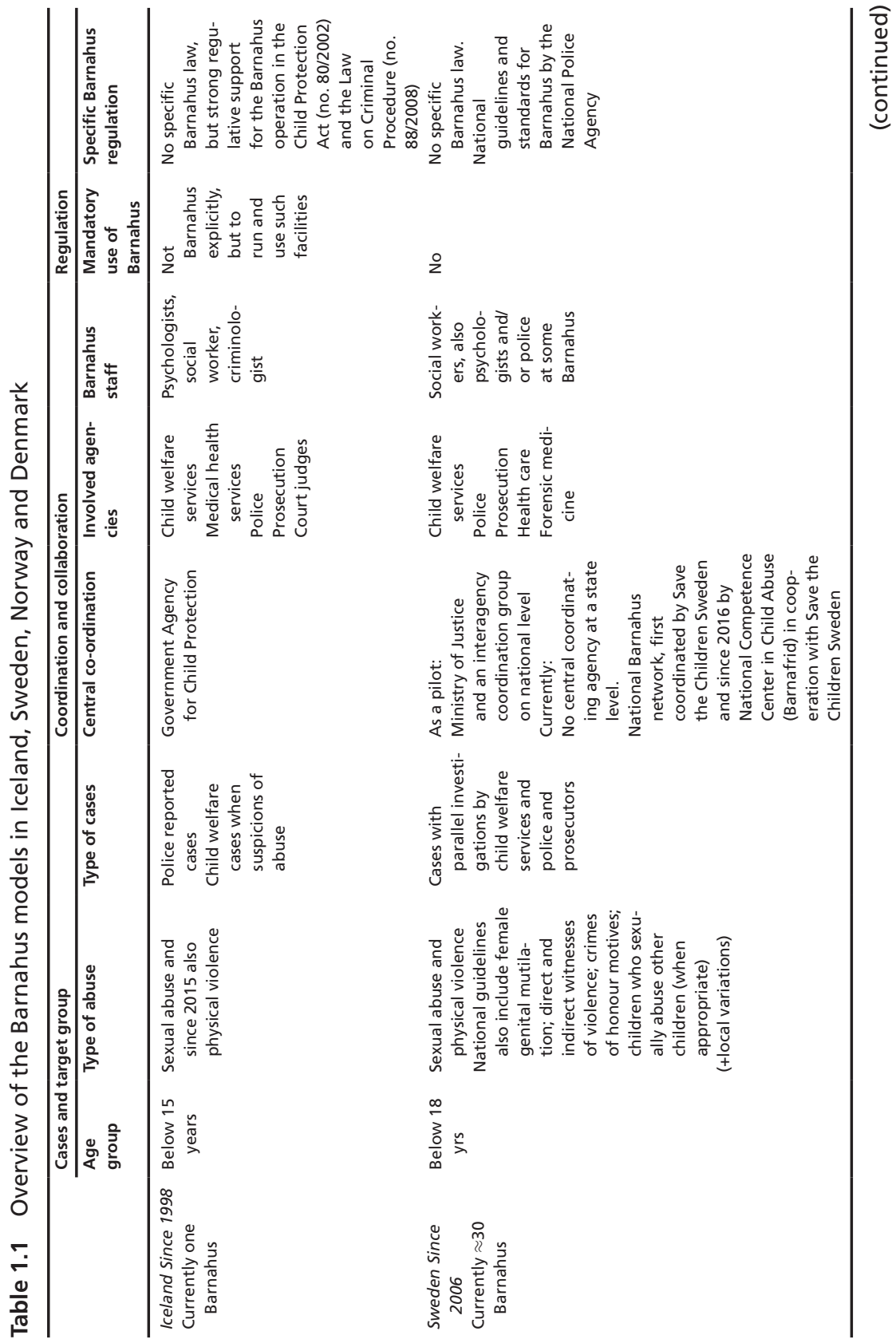




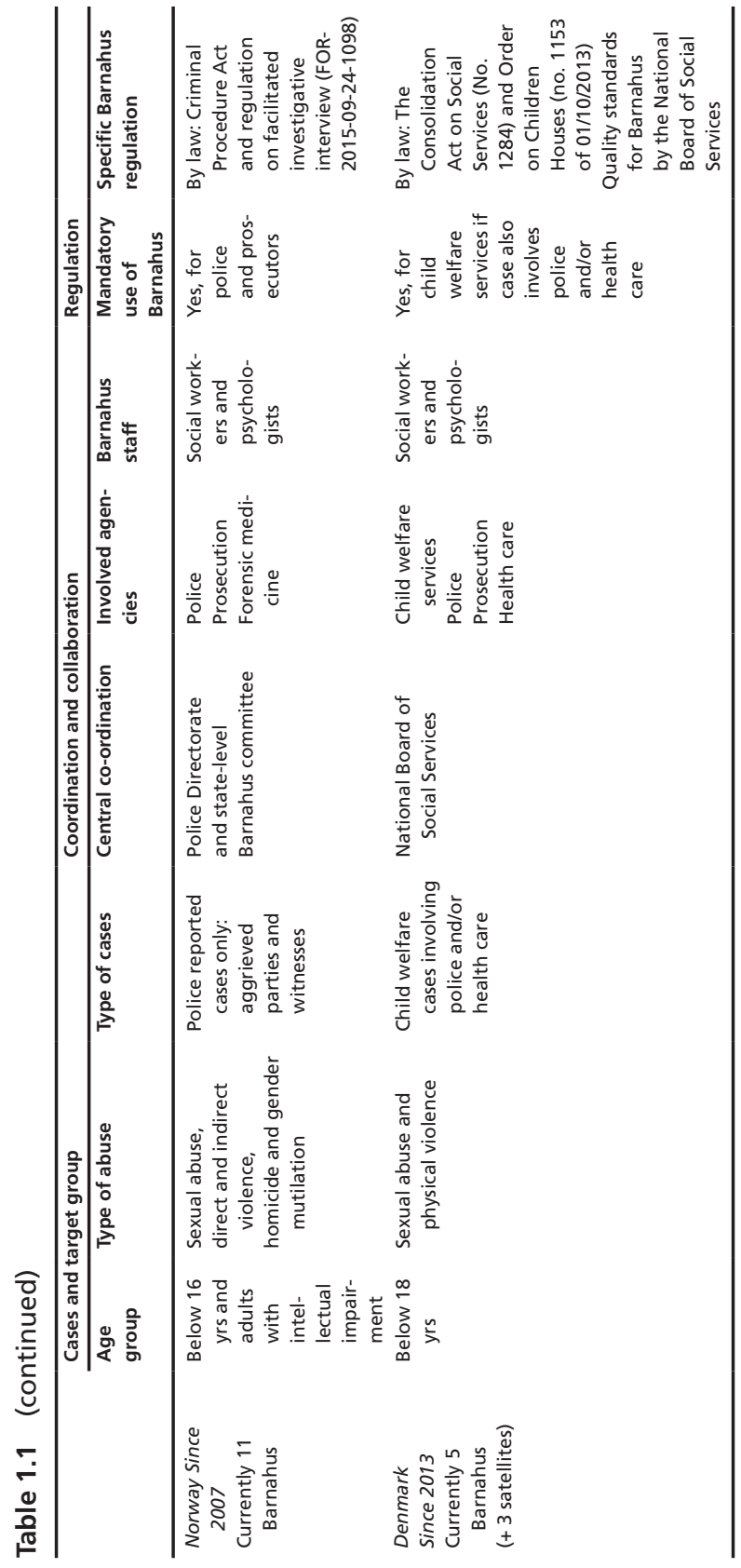




\section{Types of Abuse and Target Groups}

As described above, most of the Nordic countries include children thought to be victims of both sexual and physical abuse as part of the target group. How the target groups of the different Nordic Barnahus models are more specifically defined differs to some extent between the Nordic countries, as well as the autonomous regions. While some have formally extended the types of abuse quite expansively (see Norway and Sweden in Table 1.1), other Barnahus models have even broader, but also much more demarcated, types of abuse as part of the target group for Barnahus. To illustrate, the Åland Island's Barnahus model generally targets crimes against children while in practice mainly handling (interpersonal) violence and sexual abuse cases, and the Faroe Island's Barnahus model in practice includes all criminal behaviour against children even though the primary target group is children who have suffered sexual or physical abuse. The Greenlandic Barnahus model, in contrast, focuses on cases where children have been sexually abused or been witnesses to sexual abuse (see appendix). Similarly, there are differences in whether Barnahus includes or excludes the child's family from the target group or eventual support and treatment services offered at Barnahus (see appendix). There are also variations regarding the age of the target group, with Sweden and Denmark receiving children under 18, while Iceland and Norway have age limits of, respectively, 15 and 16. The Greenlandic Barnahus model targets children and youths aged 0-18 years, but video-recorded interviews are only used with children up to 12 years of age (cf. also the Faroe Islands).

\section{Implementation and Regulation}

The comparison shows that there are variations in how the model has been implemented in the different Nordic countries, such as whether it was implemented as a pilot project, upon a decision of the government, or not. There are also variations in how the model is regulated, which to different degrees correspond to how it has been initiated. 
In both Sweden and Norway, the Barnahus model was initiated as a pilot project by the Swedish Ministry of Justice in 2005 and the Norwegian Ministry of Justice and the Police in 2007. At that time, there was no specific Barnahus regulation in either Sweden or Norway. Today, there is still no specific Barnahus law in Sweden, even though there have been (not binding) national guidelines and criteria from 2009, issued a few years after the Barnahus pilot was initiated (Swedish National Police Agency 2009). In Norway, there was similarly no specific Barnahus regulation at the time of establishment, but in 2015 the Criminal Procedure Act was amended and new regulations of facilitated interviews were put into force (FOR-2015-09-24-1098). The new main rule states that Barnahus should be used for facilitated investigative interviews with children under the age of 16 and other vulnerable victims and witnesses in cases involving sexual abuse, direct and indirect physical violence, homicide and gender mutilation, thus making Barnahus mandatory for police and prosecutors in these cases. In Sweden, the use of Barnahus is not mandatory, which is also demonstrated by the local variations within the country, where, for instance, the child welfare services of 160 of the 290 municipalities in 2013 were connected to a Barnahus (Landberg and Svedin 2013).

In Iceland, there is no specific Barnahus law, and Barnahus is not explicitly referred to in any legal provision; however, there are regulations in both the Child Protection Act and the Law on Criminal Procedure that provide the legal basis for the Barnahus operation. The Child Protection Act mandates the Government Agency for Child Protection in Iceland to run special service centres with the objective of promoting interdisciplinary collaboration, and strengthening the coordination of agencies in the handling of cases of child protection (Art. 7; Child Protection Act). The Icelandic Government Agency for Child Protection has issued guidelines and standard settings for the local child welfare services, which are not mandatory but strongly normative for the practice of local child welfare services, not least since they may be sanctioned if a complaint is made and the standards are not met. These guidelines and standards address, for example, explorative interviews, medical examinations and therapeutic services provided by Barnahus. In 2015, there was also a legal change made in 
the Law on Criminal Procedure (nr. 88/2008) stipulating that investigative interviews of child victims up to 15 years shall be conducted under the auspice of a court judge in a facility specially designed for such purposes (Art. 9) and with the support of a specially trained person (Art. 123). These provisions are generally interpreted by court judges as mandating interviews with children below the age of 15 in Barnahus, even though this was the established practice years before the legal amendment.

In contrast, the implementation of Barnahus in Denmark followed a broad law reform that was brought into force in October 2013, called "the abuse package", resulting in the simultaneous foundation of five Barnahus and three satellites covering the whole country. As part of the abuse package, several legal changes were made within the Consolidation Act on Social Services (No. 1284) that were of importance for the Barnahus model in Denmark. A specific Barnahus law was also passed (Order on Children Houses no. 1153 of 01/10/2013) authorising the Barnahus and providing guidelines for the tasks and duties of the Barnahus. These legislative reforms made it mandatory for municipality local child welfare services to use Barnahus in child welfare cases that involve the police and/or healthcare services and that relate to violence or sexual abuse (Consolidation Act on Social Services, $\$ 50$ b). It was also made mandatory for Barnahus to assist the local child welfare services in their child welfare investigations in these cases (Order on Children Houses no. 1153 of 01/10/2013 \$1). In addition to the legal provisions, the National Board of Social Services issued common professional quality standards for the Danish Barnahus model (see appendix).

It is interesting to note that in the countries where Barnahus is mandatory by law, the obligation to use Barnahus is directed towards different agencies: in Norway towards police and prosecutors, and in Denmark towards the municipality local child welfare services. In Iceland, the specific use of Barnahus is not mandatory; however, regulative support for the use of such facilities can still be regarded as strong and also well balanced in comparison with Norway and Denmark, due to the fact that there is a regulative support to be found in both child welfare and criminal procedural regulation. 


\section{Central Coordination and Collaboration}

As a pilot project, Barnahus in Sweden was commissioned by the Swedish Ministry of Justice and coordinated by an interagency coordination group at state level. Since then, however, there has not been any central administrative coordinating agency for Barnahus in Sweden, except for the national Barnahus network established and for long coordinated by the non-governmental organisation Save the Children Sweden and since 2016 by the National Competence Centre in Child Abuse (Barnafrid) at Linköping University in cooperation with Save the Children Sweden.

In Norway, the Barnahus model is coordinated by the Police Directorate on behalf of the Ministry of Police and Public Security. Barnahus in Norway are organised as separate units within the police district where they are located, and the regular Barnahus staff are employed as civilians in the police districts. In Sweden, Barnahus do not constitute a governmental agency per se, which means that all agencies working in Barnahus are employed by their respective agencies, and the regular Barnahus staff are primarily employed within the municipality social welfare services. In Denmark, the five Barnahus are independent units that are supported and supervised by the National Board of Social Services. The administrative structure indicates a strong connection to the child welfare system in Denmark. This connection is apparently stronger than in many other Nordic Barnahus models; however, in Iceland, the Government Agency for Child Protection funds the general operation of Barnahus, employs the Barnahus staff and offers regular training in forensic interviewing and trauma-focused therapy (see appendix).

In Sweden, the Barnahus model is strongly associated with the coordination of parallel investigations (i.e. the pre-trial criminal investigation and the child welfare investigation) where Barnahus can be interpreted as a collaborative arena primarily for the child welfare services and law enforcement (police and prosecutors). Healthcare professionals, on the other hand, are not as central as in several other Nordic Barnahus models. In Sweden, the main role of Barnahus could thus be described as coordinating two parallel investigations with different objectives. 
In Norway, the Barnahus model is strongly associated with the police, and in addition, the model is more health care oriented than in several other Nordic Barnahus models, offering support and follow-up by trained therapists. In Norway, the key role could therefore be interpreted as facilitating investigative interviews in a supportive environment. The child welfare services, on the other hand, are more peripheral than in many other Nordic Barnahus models, since they are not formally a part of the collaborative model, even though they can participate when necessary, which is often the case.

In Denmark, the Barnahus model is most strongly connected to the child welfare services, even though the Barnahus also facilitates the police and their child investigative interviews. The main role of Barnahus in Denmark could thus be interpreted as assisting the municipality local child welfare services, which are the responsible and key agency in the Danish model, and through which all cases are channelled.

If we look at some of the autonomous regions, we also see strong connections between Barnahus and the child welfare system. In the Faroe Islands, the Barnahus is an integrated part of the Child Protection Agency, and since spring 2016, the Barnahus in Greenland has become part of a larger Central Advisory Unit under the Ministry of Family, Equality and Social Affairs, which deals with child welfare in all of Greenland (see appendix).

In Iceland, several changes have been made since the start of Barnahus in 1998 and today, which have developed the collaboration within Barnahus in many ways. For example, the practice of explorative interviews, initiated by the local child welfare services, has developed in addition to the (forensic) child investigative interviews. Collaborative work has also developed, from being mostly characterised by direct communication in individual cases between the local child welfare services, the police and the medical professionals, towards strengthening the role of the Barnahus staff as coordinators. This has been materialised by setting up pre-interview conferences between local child welfare services, the police and the forensic interviewer, in connection with the interview with the child, addressing both the criminal and child welfare investigation. Regular consultation meetings in Barnahus have also been 
practiced since 2016, in order to coordinate and collaborate around complex cases, especially investigations of physical (interpersonal) violence. The collaboration in the Icelandic Barnahus model could be interpreted as moving towards an increasing coordination of both the criminal and the child welfare investigation as well as a strengthening role of the Barnahus staff as coordinators.

It is also evident that there are variations (between but also, to different degrees, within countries) when the Barnahus model is implemented locally, depending on pre-existing structures, regulatory frameworks and cultural, geographical or demographical differences. In Finland, for example, the development of the Barnahus model is connected to pre-existing collaborative structures, such as the Forensic Child and Adolescent Psychiatry Units at the five university hospitals and thus has a strong relationship to healthcare and child investigative interviews by forensic psychologists, although on request by the police.

\section{Concluding Remarks}

In relation to the differences in child welfare systems noted above, varying from family service oriented or child protection oriented to a convergence towards more child-focused-oriented systems (Gilbert et al. 2011), there is a need for reflection. The child welfare systems of the Nordic countries have traditionally been seen as family service oriented, but the implementation of the Barnahus model could in one sense be interpreted as part of an ongoing move towards a child protection orientation within Nordic child welfare systems, not least since Barnahus specifically handles cases of suspected child abuse with a strong focus on the suspected crimes and the investigatory processes. For instance, the Norwegian Barnahus model is primarily focused on facilitating (forensic) child investigative interviews in a supportive environment as explained above.

The family service orientation varies between the Nordic Barnahus models, partly due to differences in whether the family as a whole is included or excluded from the target group, or the support and treatment services offered. For example, it varies whether support is given to 
the closest caregiver accompanying the child to Barnahus (often a nonsuspect), in order to be able to handle the situation and take care of the child, or whether treatment is offered to the family as a whole (cf. appendix).

The Barnahus model can also be seen as an indication of a convergence towards more child-focused or child-centred child welfare systems, since both the child-friendly settings and children's participation are central elements of the model. The implementation of Barnahus is an important part of the development towards more child-friendly justice in the Nordic countries and a strengthening of the children's rights perspective; however, the differences between the models, for instance, regarding affiliation, represent different conditions for balancing the interests of the criminal case in relation to the child welfare case. The structural affiliation of Barnahus within the police system, as in Norway, may, for instance, imply that the criminal case has higher priority (cf. Bakketeig, Chap. 13).

Evidently, there are several differences in how the implementation of the Barnahus model has taken shape in various national policy contexts. This leads to different conditions for interagency collaboration as well as more specialised investigation processes to evolve in practice, which the following chapters will elaborate further.

\section{Outline of the Book}

\section{Themes and Chapters}

The book is divided into four broad themes. The first theme relates to the idea of Barnahus as a supportive context for victimised children, which is an important part of the model's basic aim of being a childfriendly service for children. This part addresses the question of whether the Barnahus context and routines are actually experienced as supportive by children and their supportive adults. Kari Stefansen writes in Chap. 2 about the role of the material in staging a child-friendly atmosphere at Barnahus, using data from the Norwegian context. She analyses both professional views and the experiences of children and 
accompanying adults who have been at Barnahus because of a suspected crime against the child. Ann-Margreth Olsson and Maria Kläfverud from Sweden focus in Chap. 3 on children's understandings of Barnahus and the particularly difficult situation for children of being summoned to Barnahus when their parents or persons close to the parents are suspected of the crime-and thus are not informed about the child's visit to the Barnahus. An important part of offering a supportive context for children in Barnahus is also that the methods and tools for crisis intervention are evidence based. Drawing on a study in Sweden, in Chap. 4 Johanna Thulin and Cecilia Kjellgren introduce and discuss an intervention aimed at both children and parents in families where one or both parents have used physical violence against the child.

Theme II relates to the (forensic) child investigative interview. In Chap. 5, Trond Myklebust describes the Nordic model of handling children's testimonies and discusses today's interviewing procedures and the training provided for interviewers. Gunn Astrid Baugerud and Miriam Sinkerud Johnson present a revised version of the NICHD protocol in Chap. 6, which focuses on enhanced socio-emotional support from the interviewers in order to manage children's reluctance to reveal abuse. In Chap. 7, Julia Korkman, Tom Pakkanen and Taina Laajasalo present the framework for specialised university hospital units in Finland, used for investigating suspected crimes against children when requested by the police. Special attention is directed towards the use of forensic psychology expertise and a hypothesis-testing approach in relation to the (forensic) child investigative interview and pre-trial (criminal) investigation. In Chap. 8, Åse Langballe and Tone Davik discuss a new sequential interview model that is tailored to the needs of preschool children when they participate in investigative interviews in Barnahus.

The third theme covers different dimensions of children's rights in relation to Barnahus. In Chap. 9, Hrefna Fridriksdottir and Anni G. Haugen present a method for the analysis of interdisciplinary child rights justice systems, which aims to identify international principles and the main challenges in their practical application in handling cases concerning the sexual abuse of children. In Chap. 10, Anna Kaldal, Åsa Landberg, Maria Eriksson and Carl Göran Svedin discuss children's rights to information in a criminal investigation in Barnahus, from a 
child's rights perspective, according to both international law and Swedish national law. In Chap. 11, Maria Forsman discusses children's legal representatives in Sweden and their role in Barnahus.

The last theme (IV) addresses professional autonomy and interagency collaboration. These are core elements in Barnahus as a multiprofessional collaborative model with the main aim of facilitating and improving interagency collaboration. As the chapters will show, professional autonomy and collaboration create tensions and challenges in an interagency model, which require balancing. Susanna Johansson relates to the Swedish context and shows in Chap. 12 how Barnahus collaboration spans different regulatory fields and brings together conflicting logics, creating an institutional tension between "justice" and "welfare". Her chapter analyses collaboration in Barnahus in a critical manner, drawing on institutional theory and a three-dimensional concept of power. Elisiv Bakketeig explores the issue of conflicting logics further in Chap. 13 by discussing whether, and how, juridification manifests in the Norwegian Barnahus model using the Swedish Barnahus model as a point of reference. She discusses factors that may stimulate or constrain processes of juridification in the Norwegian model. In Chap. 14, Lene Mosegaard Søbjerg explores how the establishment of Barnahus in Denmark has been perceived by child welfare workers in the local municipalities. More precisely she discusses how the establishment of Barnahus in Denmark affected the capability of child welfare caseworkers to work holistically with abused children and how this relates to Barnahus as an integrated service. Finally, in Chap. 15 Anja Bredal and Kari Stefansen discuss a pilot project in Norway called "project November" which involves adapting the main features of the Barnahus model with the aim of developing integrated services for adult victims of interpersonal violence. They highlight the importance of analysing the local landscape of services before new collaborative models are implemented.

In the concluding chapter, we comment on the contributions in the book and identify key challenges and potentials relating to the Barnahus model, both within a Nordic welfare state context and beyond. We also introduce Barnahus as an emerging organisational field and a corresponding field of research. 


\section{Notes}

1. Lithuania is one of the Baltic Sea States, and the Council of the Baltic Sea States has received EU funding for a project aimed at promoting child-friendly multidisciplinary and interagency services for child victims of violence and sexual assault (the PROMISE project, www.cbss.org/ promise-kick-meeting/).

2. We discuss the latter topic in the concluding chapter in this book.

3. The discussion below is informed by NGO and governmental reports, policy documents and guidelines on international and European levels, as well as commissioned research on the Barnahus model in the early phase after implementation (e.g. Skybak 2004; Diesen 2002; Landberg and Svedin 2013; Save the Children Sweden 2009; Gudbrandsson 2010; Norwegian Ministry of Justice and the Police 2006; Swedish Ministry of Justice 2005; Bakketeig et al. 2012; Stefansen et al. 2012; Åström and Rejmer 2008; Kaldal et al. 2010). The information on the CAC model stems partly from the National Children's Advocacy Center web page and partly from existing research and evaluation studies (see, for example, Wolfteich and Loggins 2007; Cross et al. 2007; Jones et al. 2007; Faller and Palusci 2007; Walsh et al. 2008; Miller and Rubin 2009).

4. In addition, the Nordic Barnahus models have a low threshold for cases in accordance with the definitions of sexual abuse and (interpersonal) violence in the criminal codes of the respective countries. Taken together, this means that the Barnahus model deals with a broader target group than the CAC and handles many cases with a high degree of uncertainty, not least when it comes to evidence for court proceedings.

5. In Sweden, the convention was ratified in 1990 and has since then been transformed through implementation in several areas of law. Today, there is a bill with a suggestion of an incorporation of the convention in Sweden (SOU 2016: 19Barnkonventionen blir svensk lag).

6. It is important to note, however, that the system categorisations are quite general descriptions of how the child welfare and criminal justice systems of the Nordic welfare states are designed and meant to work. It does not mean that the systems always work in the intended way. We are currently witnessing examples of "system-failures" within the Nordic countries due to, for instance, economic burdens or case overloads (see, for example, Backe-Hansen et al. 2016). 
7. This is not the case in, for example, Belgium or the Netherlands. Note also that in Finland, mandatory reporting directly to the police has been enforced since 2015 in cases of suspected child abuse.

\section{References}

Åström, Karsten and Annika Rejmer. 2008. "Det blir nog bättre för barnen..." Slutrapport i utvärderingen av nationell försöksverksamhet med barnahus 2006-2007. Lund: Lund University.

Backe-Hansen, Elisabeth, Ingrid Höjer, Yvonne Sjöblom and Jan Storø. 2013. "Out of home care in Norway and Sweden-Similar and different." Psychosocial Intervention 22:193-202.

Backe-Hansen, Elisabeth, Ingrid Smette and Camilla Vislie. Forthcoming 2016. Kunnskapsoppsummering: Vold mot barn og systemsvikt. Report for the governmental committee on violence against children and system failure. Bakketeig, Elisiv, Mette Berg, Trond Myklebust, and Kari Stefansen. 2012. Barnehusevalueringen 2012, delrapport 1: Barnehusmodellens implikasjoner for politiets arbeid med fokus på dommeravhør og rettsmedisinsk undersøkelse. Oslo: PHS Forskning.

Bakketeig, Elisiv. 2000. Rettsapparatet som sosialt system i saker om seksuelle overgrep mot barn. Avhandling levert til graden dr.philos ved Universitetet i Oslo. Oslo: Universitetet i Oslo.

Bakketeig, Elisiv and Lotte T. Bergan. 2013. Om ungdoms medvirking ved plassering i fosterhjem. Fosterhjem for barns behov. Rapport fra et fireårig forskningsprogram, ed. E. Backe-Hansen, Toril Havik and Arne Backer Grønningsæter. NOVA-rapport 16/13, 85-108. Oslo: NOVA.

Blomberg, Helena, Clary Corander, Christian Kroll, Anna Meeuwisse, Roberto Scaramuzzino and Hans Swärd. 2011. "A Nordic model in child welfare?" In: Social work and child welfare politics. Through Nordic lenses, ed. Hannele Forsberg and Teppo Kröger, 29-45. Bristol: Policy Press.

Christiansen, Niels Finn, and Pirjo Markkola. 2006. Introduction. In The Nordic model of welfare: A historical reappraisal, eds. Niels F. Christiansen, Klaus Petersen, Nils Edling, and Per Haave. Copenhagen: Museum Tusculanum Press.

Council of Europe. 2010. Guidelines of the Committee of Ministers of the Council of Europe on child-friendly justice. Strasbourg: Council of Europe Publishing. 
Council of Europe Convention on the Protection of Children Against Sexual Exploitation and Sexual Abuse and Explanatory Report. (Lanzarote Convention). 2008. Strasbourg.

Cross, Theodore P., Lisa M. Jones, Wendy A. Walsh, Monique Simone and David Kolko. 2007."Child forensic interviewing in Children's Advocacy Centers: Empirical data on a practical model." Child Abuse \& Neglect 31: 1031-1052.

Czarniawska, Barbara, and Guje Sevón. 1996. Translating organizational change. New York: Walter de Gruyter.

Danelius, Hans. 2015. Mänskliga rättigheter i europeisk praxis: en kommentar till Europakonventionen om de mänskliga rättigheterna. Stockholm: Norstedts juridik.

Diesen, Christian. 2002. Child abuse and adult justice. A comparative study of different European Criminal Justice Systems handling of cases concerning child sexual abuse. Stockholm: International Save the Children Alliance.

Donzelot, Jacques. 1997. The policing of families. London: Johns Hopkins University Press.

Eriksson, Maria. 2012. Participation for children exposed to domestic violence? Social workers' approaches and children's strategies. European Journal of Social Work 15 (2): 205-221.

Esping-Andersen, Gøsta. 1990. The three worlds of welfare capitalism. Cambridge: Polity Press.

European Union Agency for Fundamental Rights. FRA. 2015. Child-friendly justice-Perspectives and experiences of professionals on children's participation in civil and criminal judicial proceedings in 10 EU Member States.

Faller, Kathleen C.and Vincent J. Palusci. 2007. Children's Advocacy Centers: Do they lead to positive outcomes? Child Abuse \& Neglect 31: 1021-1029.

Forsberg, Hannele, and Teppo Kröger. 2011. Social work and child welfare politics. Through Nordic lenses. Bristol: Policy Press.

Forsman, Maria. 2013. Rättsliga ingripanden vid föräldrars våld och övergrepp mot barn. Stockholm: Norstedts Juridik.

Freeman, Michael. 2012. Law and childhood studies: Current legal issues. New York: Oxford University Press.

Gilbert, Neil, Nigel Parton and Marit Skivenes. 2011. Child protection systems. International trends and orientations. New York: Oxford University Press.

Gilbert, Gilbert. 1997. Combatting child abuse: International perspectives and trends. New York: Oxford University Press.

Gudbrandsson, Bragi. 2010."Towards a child-friendly justice and support for child victims of sexual abuse." Protecting children from sexual violence, a comprehensive approach. Strasbourg: Council of Europe. 
Hacking, Ian. 1999. The social construction of what?. Cambridge: Harvard University Press.

Hennum, Ragnhild. 2006. "Dommeravhør og menneskerettigheter - konvensjonspraksis om særlig sårbare vitner." In Festskrift til Carl August Fleischer, ed. Ole Kristian Fauchald, Henning Jakhelln og Aslak Syse. Oslo: Universitetsforlaget.

James, Allison and Alan Prout. 2014 [1990]. Constructing and reconstructing childhood: Contemporary issues in the sociological study of childhood. London: Routledge.

Johansson, Susanna. 2011. Rätt, makt och institutionell förändring. En kritisk analys av myndigheters samverkan i barnahus. Diss. Lund: Lund Studies in Sociology of Law 31, Lund University.

Johansson, Susanna. 2012."Diffusion and governance of 'Barnahus' in the Nordic countries: Report from an ongoing project." Journal of Scandinavian Studies in Criminology and Crime Prevention 13(1): 69-84.

Jones, Lisa, Theodore P. Cross, Wendy A. Walsh and Monique Simone. 2007. "Do Children's Advocacy Centers improve families' experiences of child sexual abuse investigations?” Child Abuse \& Neglect 31: 1069-1085.

Kaldal, Anna. 2010. Parallella processer. En rättsvetenskaplig studie av riskbedömningar i vårdnads- och LVU-mål. Stockholm: Jure förlag.

Kaldal, Anna, Christian Diesen, Johan Beije and Eva F. Diesen. 2010. Barnahusutredningen 2010. Stockholm: Jure förlag.

Landberg, Åsa and Carl Göran Svedin. 2013. Inuti ett barnahus. En kvalitetsgranskning av 23 svenska verksamheter. Stockholm: Save the Children Sweden.

Leviner, Pernilla. 2011. Rättsliga dilemman i socialtjänstens barnskyddsarbete. Stockholm: Jure förlag.

Lorenz, Walter. 1994. Social work in a changing Europe. London: Routledge.

Miller and Rubin. 2009. The contribution of Children's Advocacy Centers to felony prosecutions of child sexual abuse. Child Abuse and Neglect 33: $12-18$.

Norwegian Ministry of Justice and the Police. 2006. Barnas hus. Rapport om etablering av et pilotprosjekt med ny avhørsmodellfor barn som har vært utsatt for overgrep m.m. Oslo: Norwegian Ministry of Justice and the Police. Ponnert, Lina (ed.). 2015. Utredningsarbete i den sociala barnavairden. Malmö: Gleerups.

Røvik, Kjell A. 2000. Moderna organisationer - trender inom organisationstänkandet vid millennieskiftet. Malmö: Liber. 
Røvik, Kjell A. 2016. Knowledge transfer as translation: Review and elements of an instrumental theory. International Journal of Management Reviews 18 (3): 290-310.

Sandberg, Kirsten. 2016. "Barns rett til å bli hørt" In Barnekonvensjonen, Barns rettigheter i Norge, eds. Njål Høstmælingen, Elin Saga Kjørholt and Kirsten Sandberg 3 ed., 92-122. Oslo: Universitetsforlaget.

Save the Children Sweden. 2009. Gemensamma kriterier! Innehallet $i$ ett barnahus i 10 punkter. Stockholm: Save the Children Sweden.

Skjørten, Kristin, Mona Iren Hauge, Åse Langballe, Jon H. Schultz and Carolina Øverlien. 2016. “Å se det utsatte barnet.” I: Barn, vold og traumer. Møter med unge i utsatte livsssituasjoner, eds. C. Øverlien, M.I. Hauge and J.H. Schultz, 93-107. Oslo: Universitetsforlaget.

Skybak, Thale. 2004. Barnas hus - et helhetlig og barnevennlig tilbud til barn som har vært utsatt for seksuelt misbruk. Oslo: Save the Children Norway.

Stefansen, Kari, Tonje Gundersen and Elisiv Bakketeig. 2012. Barnehusevalueringen 2012, delrapport 2. En undersøkelse blant barn og pårørende, samarbeidspartnere, ledere og ansatte. Oslo: NOVA, rapport nr. 9.

Sutorius, Helena, and Anna Kaldal. 2003. Bevispröuning vid sexualbrott. Stockholm: Norstedts juridik.

Swedish Ministry of Justice. 2005. Uppdrag att medverka till etablering av flera försöksverksamheter med samverkan under gemensamt tak vid utredningar kring barn som misstänks vara utsatta för allvarliga brott. (Government decision). Stockholm: Swedish Ministry of Justice.

Swedish National Board of Health and Welfare. 2000. Sexuella övergrepp mot barn. En studie av samarbetet $i$ samrådsgrupper. Stockholm: Swedish National Board of Health and Welfare.

Swedish National Board of Health and Welfare,Swedish National Police Agency, Swedish Prosecution Authority and Swedish National Board of Forensic Medicine. 2008. Barnahus - försöksverksamhet med samverkan under gemensamt tak vid misstanke om brott mot barn. Stockholm: Swedish National Board of Health and Welfare.

Swedish National Police Agency. 2009. Progress report regarding a government commission to establish common national guidelines for multiagency collaboration in inquires relating to children who may be exposed to crime and standards for national Children's Advocacy Centres. (Official translation). Stockholm: Swedish National Police Agency.

United Nations Committee on the Rights of the Child. 2009. General Comment no. 12 on the right of the child to be heard. CRC/C/GC/12. 
United Nations Committee on the Rights of the Child. 2013. General Comment no. 14 on the rights of the child to have his or her best interests taken as a primary consideration. CRC/C/GC/14.

United Nations Economic and Social Council Resolution 2005/20, Guidelines on Justice in Matters Involving Child Victims and Witnesses of Crime. (UN Economic and Social Council Resolution 2005/20).

Walsh, Wendy, Tonya Lippert, Theodore P. Cross, Danielle M. Maurice and Karen S. Davison. 2008. "How long to prosecute child sexual abuse for a community using a children's advocacy center and two comparison communities?" Child Maltreatment 13(1): 3-13.

Wolfteich, Paul and Brittany Loggins. 2007. "Evaluation of the Children's Advocacy Center Model: Efficiency, legal and revictimization Outcomes." Child and Adolescent Social Work Journal 24(4): 333-352.

Open Access This chapter is licensed under the terms of the Creative Commons Attribution 4.0 International License (http://creativecommons. org/licenses/by/4.0/), which permits use, sharing, adaptation, distribution and reproduction in any medium or format, as long as you give appropriate credit to the original author(s) and the source, provide a link to the Creative Commons license and indicate if changes were made.

The images or other third party material in this chapter are included in the chapter's Creative Commons license, unless indicated otherwise in a credit line to the material. If material is not included in the chapter's Creative Commons license and your intended use is not permitted by statutory regulation or exceeds the permitted use, you will need to obtain permission directly from the copyright holder.

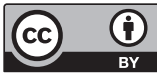

